\title{
Participative Journal
}

Jurnal Pengabdian Pada Masyarakat

Vol. 01, No. 01, April 2021

Homepage journal: https://jurnal.jurmat.com/index.php/pj

\section{PENGEMBANGAN KOMPETENSI PROFESSIONALISME GURU MADRASAH MELALUI PELATIHAN PENELITIAN TINDAKAN KELAS (PTK)}

\author{
M. Habib Husnial Pardi*1 \\ *Affiliasi: Universitas Islam Negeri Mataram
}

\begin{abstract}
Madrasah Aliyah Bayyinul Ulum Santong has quite a number of certified teachers as capital in developing madrasas to become excellent madrasas. Human resources: teachers as a strategic component in supporting the quality of learning need to be improved on an ongoing basis, one of which is training or Classroom Action Research (CAR) workshops. This activity aims to improve the quality of learning in the classroom. The participants in this activity were all 14 subject certification teachers in the Madrasah Aliyah Bayyinul Ulum environment. The method of activities used is workshops and training with 3 main activities, namely deepening the material and compiling the PTK proposal through workshops, planning PTK through group discussion activities (Focus Group discussions), and implementing PTK through guidance on the implementation of PTK. The result is that the teachers understand better $C A R$, and realize the urgency of CAR in improving the quality of learning in the classroom. With the practical ability to compile proposals and to be followed up by research activities, a research culture will be built among teachers as a solution in solving various learning problems which in turn will increase the competence of teacher professionalism itself.
\end{abstract}

Keywords. training, PTK, teacher certification, Madrasah

Journal Info:

Received, 10 Februari 2021 | Revised, 05 Maret 2021 | Published, 12 April 2021

\footnotetext{
${ }^{1}$ Corresponden to the author: Prodi Tadris Matematika, UIN Mataram.

Jl. Gajah Mada Jempong, Indonesia (83116), email address : muhhabib71@uinmataram.ac.id
} 


\begin{abstract}
Abstrak
Madrasah Aliyah Bayyinul Ulum Santong memiliki cukup banyak guru sertifikasi sebagai modal dalam mengembangkan madrasah menjadi madrasah unggulan. Sumber daya manusia: guru sebagai komponen strategis dalam mendukung kualitas pembelajaran perlu ditingkatkan secara berkelanjutan salah satunya adalah pelatihan (training) atau workshop Penelitian Tindakan Kelas (PTK). Kegiatan ini bertujuan untuk meningkatkan kualitas pembelajaran di kelas. Adapun partisipan dalam kegiatan ini adalah semua guru sertifikasi mata pelajaran yang berjumlah 14 orang yang dilingkungan Madrasah Aliyah Bayyinul Ulum. Metode kegiatan yang digunakan adalah workshop dan training dengan 3 kegiatan pokok, yaitu pendalaman materi dan penyusunan proposal PTK melalui kegiatan workshop, Perencanan PTK melalui kegiatan diskusi kelompok (Fokus Group discussion), dan praktik pelaksanaan PTK melalui kegiatan bimbingan pelaksanaan PTK. Hasilnya adalah para guru lebih memahami PTK, dan menyadari urgensi PTK dalam memperbaiki kualitas pembelajaran di kelas. Dengan kemampuan praktik menyusun proposal dan difollow up kegiatan penelitian maka akan terbangun budaya research di kalangan para guru sebagai sebuah solusi dalam menyelesaikan berbagai persoalan pembelajaran yang pada akhirnya akan meningkatkan kompetensi professionalisme guru itu sendiri.
\end{abstract}

Kata Kunci: pelatihan, PTK, Guru sertifikasi, Madrasah

\title{
Pendahuluan
}

Madrasah Aliyah Swasta Bayyinul Ulum Santong telah berdiri sejak tahun 1999 di bawah naungan Pondok Pesantren Bayyinul Ulum Santong. Berdasarkan data temuan dilapangan, Madrasah Aliyah ini merupakan madrasah aliyah terbesar di Kabupaten Lombok Utara jika ditinjau dari sejumlah indikator yaitu (1) jumlah peserta didik, dimana jumlah peserta didik di madrasah ini mencapai 280 siswa dari kelas $X$ hingga kelas XII dimana masing-masing angkatan terdiri atas tiga rombongan belajar yang berisi sekitar 30-35 siswa per kelas; (2) status akriditasi sekolah, dimana status akriditasi Madrasah Aliyah Bayyinul Ulum Santong tergolong baik, yaitu terakriditasi B. Ditinjau dari kualifikasi tenaga pendidik dan tenaga kependidikan, Madrasah Aliyah Bayyinul Ulum Santing memiliki tenaga pendidik dan tenaga kependidikan yang tergolong baik dimana keseluruhan tenaga pendidik dan kependidikan di madrasah ini berkualifikasi S1 dan 54\% dari mereka sudah tersertifikasi.

Adanya tuntutan yang lebih terhadap guru tersertifikasi, dimana mereka dituntut untuk menghasilkan kajian ilmiah dalam bentuk Penelitian Tindakan Kelas (PTK). Tuntutan ini harus didukung oleh kesiapan dan kemampuan guru di lapangan. Sebab realitas di lapangan menunjukkan bahwa tidak semua guru sertifikasi memiliki kemampuan bahkan bisa melaksanakan kegiatan PTK dengan baik. Karena itu, kegiatan pelatihan PTK nampaknya sangat dibutuhkan oleh para guru di madrasah ini. Menurut informasi dari studi awal, Madrasah Aliyah Bayyinul Ulum 
sebelumnya telah terlibat dalam kegiatan pelatihan PTK (diklat) yang dilakukan oleh pemerintah setempat akan tetapi hasilnya belum maksimal.

Para ahli pendidikan dan pengajaran mengajukan sejumlah metode yang dapat digunakan untuk meningkatkan kompetensi dan kreatifitas guru dalam menyelenggarakan pembelajaran dan salah satunya yang paling menjanjikan adalah proses perbaikan dan peningkatan kualitas pembelajaran melalui kegiatan Penelitian Tindakan Kelas (PTK). Pengembangan kompetensi profesionalisme guru dapat dilakukan salah satunya melalui keterlibatan guru dalam kegiatan Penelitian Tindakan Kelas (PTK) yang dilakukan secara berkesinambungan (sustainability). (Ahmar, 2005; Jones \& Song, 2005; Kirkey, 2005; McIntosh, 2005; McNeiff, 1992).

Berbagai riset lain telah dilakukan terkait dengan peningkatan kualtias pengajaran guru dan ditemukan bahwa PTK dapat meningkatkan profesionalisme guru di dunia pendidikan (Ahmar, 2005; Jones \& Song, 2005; Kirkey, 2005; McIntosh, 2005; McNeiff, 1992). Hal ini dikarenakan PTK dapat membantu: (1) pengembangan kompetensi guru dalam menyelesaikan masalah pembelajaran mencakup kualitas isi, efisiensi, dan efektivitas pembelajaran, proses, dan hasil belajar siswa, (2) peningkatan kemampuan pembelajaran akan berdampak pada peningkatan kompetensi kepribadian, sosial, dan profesional guru (Prendergast, 2002).

Lewin (dalam Prendergast, 2002:2) secara tegas menyatakan, bahwa Penelitian Tindakan Kelas (Classroom Action Research) merupakan cara guru untuk mengorganisasikan pembelajaran berdasarkan pengalamannya sendiri atau pengalamannya berkolaborasi dengan guru lain. Sementara itu, Calhoun dan Glanz (dalam Prendergast, 2002:2) menyatakan, bahwa penelitian tindakan kelas merupakan suatu metode untuk memberdayakan guru yang mampu mendukung kinerja kreatif Sekolah. Di samping itu, Prendergast (2002:3) juga menyatakan, bahwa penelitian tindakan kelas merupakan wahana bagi guru untuk melakukan refleksi dan tindakan secara sistematis dalam pengajarannya untuk memperbaiki proses dan hasil belajar siswa. Cole dan Knowles (Prendergast (2002:3-4) menyatakan bahwa, penelitian tindakan kelas dapat mengarahkan para guru untuk melakukan kolaborasi, refleksi, dan bertanya satu dengan yang lain dengan tujuan tidak hanya tentang program dan metode mengajar, tetapi juga membantu para guru mengembangkan hubungan-hubungan personal.

Pernyataan Knowles tersebut juga didukung oleh Noffke (Prendergast (2002:5), bahwa penelitian tindakan kelas dapat mendorong para guru melakukan refleksi terhadap praktek pembelajarannya untuk membangun pemahaman mendalam dan mengembangkan hubunganhubungan personal dan sosial antar guru.Whitehead (1993) menyatakan, bahwa penelitian tindakan kelas dapat memfasilitasi guru untuk mengembangkan pemahaman tentang pedagogi dalam rangka memperbaiki pembelajarannya.Penjelasan-penjelasan teoretis tersebut mengindikasikan, bahwa pemahaman danpenerapan PTK akan membantu para guru untuk mengembangkan keempat kompetensi yangdipersyaratkan oleh UURI Nomor 14 Tahun 2005. PTK 
akan memfasilitasi guru untuk meningkatkan kompetensi-kompetensi profesional, pedagogi, kepribadian, dan sosial.

Melihat realitas dan hasil research di atas, maka kegiatan pengabdian fokus pada permasalahan di atas yaitu meningkatkan kualitas guru melalui program pelatihan Penelitian Tindakan Kelas (PTK). Asumsi yang bisa dibangun adalah jika tenaga pendidik (guru) berkualitas dan berkinerja dalam melaksanakan kegiatan pembelajaran maka akan tercipta mutu lulusan yang lebih baik dan pada gilirannya meningkatkan mutu madrasah tersebut.

Hal ini karena guru memiliki posisi yang strategis di sebuah institusi pendidikan dimana mereka memegang peranan penting dalam menentukan kualitas dan keberhasilan proses pembelajaran di kelas. Keberhasilan ini secara langsung berpengaruh pada terciptanya peningkatan mutu lulusan dan bahkan bisa dijadikan sebagai salah faktor penentu apakah institusi pendidikan tersebut dapat dikatakan berkualitas atau tidak.

Para guru dituntut untuk selalu melakukan langkah-langkah inovatif, melakukan evaluasi diri dan refleksi terhadap pembelajaran yang telah dilakukannya. Tingkat inovasi guru sebagai bentuk perubahan paradigma guru tersebut dapat ditingkatkan melalui kegiatan evaluasi diri (refleksi diri) yang dilakukan secara sistematis dan terstruktur terhadap praktik pembelajaran yang telah dilakukan melalui mekanisme yang disebut dengan Penelitian Tindakan Kelas (PTK).

Melalui peneltian tindakan kelas, guru dapat meningkatkan mutu dan kualitas pembelajarannya karena penelitian tindakan kelas secara umum dilaksanakan untuk memecahkan pemasalahan-permasalahan yang terjadi di dalam kelas sehingga proses pembelajaran dapat berjalan secara efektif. Disamping itu penelitian tindakan kelas dapat menumbuhkan sikap mandiri dan kritis guru terhadap situasi dan keadan di dalam kelas yang diajarnya.

\section{Metode}

Kegiatan pengabdian pada masyarakat ini adalah kegiatan dalam rangka mengembangkan kompetensi professionalisme guru yang bersertifikasi melalui kegiatan pelatihan Penelitian Tindakan Kelas (PTK) di Madrasah Bayyinul Ulum Santong. Program pengembangan ini melalui kegiatan workshop and Focus Group Discussion dengan metode ceramah, diskusi, dan Guide Patner meliputi 3 kegiatan pokok, yaitu pendalaman materi PTK, diskusi kelompok (Fokus Group discussion) pemetaan problem pembelajaran di kelas, dan praktik penyusunan proposal dan implementasi PTK melalui kegiatan bimbingan.

Kegiatan pertama, yaitu workshop, dimaksud untuk membantu peserta workshop untuk memahami kembali mengenai PTK. Penulis meyakini bahwa PTK bagi sarjana pendidikan bukan sesuatu yang asing dan sulit dilaksanakan. Bermodal pengetahuan metode penelitian dan pengalaman menulis skripsi, maka tentu kegiatan PTK akan terasa tidak begitu menyulitkan. 
Kegiatan kedua, yaitu Focus Group Discussion. Secara umum kesulitan yang sering diamali oleh para guru maupun peneliti pada umumnya adalah bagaimana menentukan atau memilih masalah yang akan dijadikan sebagai persoalan penelitian khususnya penelitian PTK. Mereka menyadari bahwa banyak masalah di sekitar mereka, banyak persoalan-persoalan pembelajaran yang tidak pernah dapat diselesaikan, dan lain-lain. Karena itu, melalui kegiatan Focus Group Discussion peserta kegiatan akan diajak berdiskusi dn dilatih bagaimana cara memetakan persoalanpersoalan yang ada sehingga bisa dijadikan sebagai masalah peneltian PTK.

Kegiatan ketiga, kegiatan terakhir ini dimaksudkan untuk menguatkan kegiatan sebelumnya dalam bentuk praktik penyusunan proposal dan implementasi PTK. Atas dasar pertimbangan keterbatasan waktu, maka kegiatan praktik penyusunan proposal PTK akan dilakukan random sample dan kelompok sesuai jadwal mengajar guru bersangkutan. Artinya, kegiatan praktik ini semaksimal mungkin tidak akan mengganggu kegiatan proses pembelajaran. Teknis pelaksanaannya adalah salah satu guru sebagai peneliti dan yang lainnya sebagai observer. Proses dan pembuatan hasil praktik PTK ini akan dibahas bersama-sama antara dosen pendamping dan peserta kegiatan.

\section{Hasil Dan Pembahasan}

Salah satu kegiatan Tridharma Perguruan yaitu pengabdian kepada masyarakat. Kegiatan pengabdian pada masayarakat ini dilakukan di salah satu Madrasah Desa Santong kab, Lombok Utara yaitu Madrasah Aliyah Swasta Bayyinul Ulum Santong. Survey dan observasi dilakukan selama 3 x dan dari hasil observasi dan survey ditemukan beberapa persoalan yang relevan diangkat menjadi bahan/tema dalam kegiatan ini salah satunya peningkatan kemampuan Penelitian Tindakan Kelas bagi guru khususnya guru yang bersertifikasi.

Data awal dari hasil survey, observasi dan interview langsung dengan para guru di MAS Bayyinul Ulum didiskusikan dan dianalisis dengan beberapa teman sejawat. Ini berarti bahwa pemilihan tema tersebut sifatnya tidak asal-asalan tetapi melalui proses ilmiah dan sangat urgens untuk dilaksanakan. Pemilihan tema tentang Penelitian Tindakan Kelas selain usul atau permintaan pada guru, juga atas pertimbangan bahwa kemampuan Penelitian Tindakan Kelas para guru ratarata di bawah standar. Hal ini akan berdampak pada terhambatnya peningkatan kompetensi profesionalisme mereka dalam menjalan tugas sehari-hari yang selalu dihadapkan oleh berbagai persoalan pendidikan. Di tambah lagi dengan data di lapangan menunjukkan bahwa kemampuan guru dalam proses pembelajaran sangat terbatas terutama dalam penguasaan metode pembelajaran. Di sisi lain, kegiatan PTK merupakan salah satu solusi dalam menyelesaikan persoalan pembelajaran di kelas. 

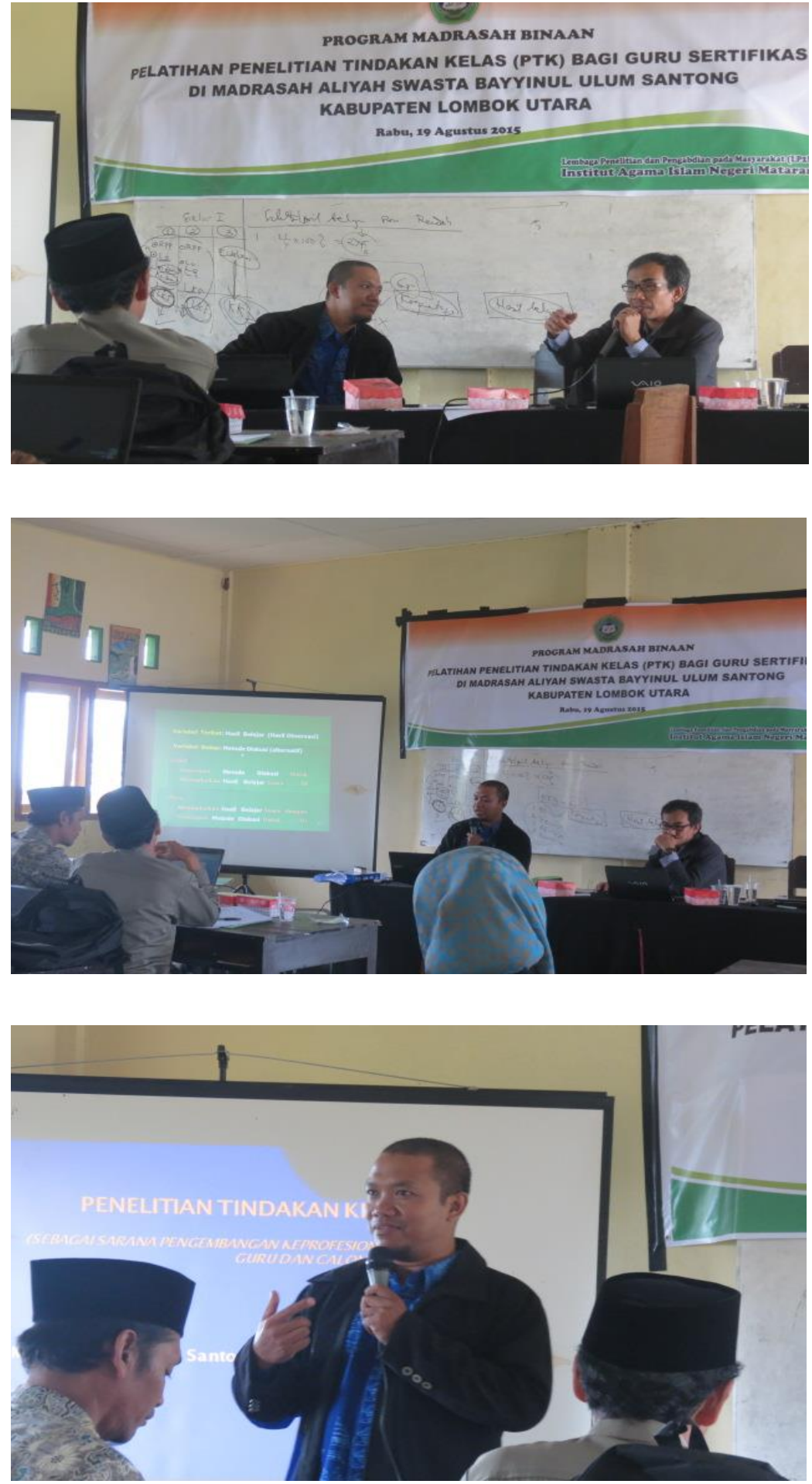

\section{Gambar 1:}

Pelaksanaan kegiatan pertama: Peyampaian Materi PTK melalui metode ceramah diskusi, tanya jawab serta praktik

\section{Gambar 2:}

Peyampaian Materi PTK melalui metode ceramah diskusi, tanya jawab serta praktik bersama nara sumber Lalu Sucipto salah satu dosen FTK UIN Mataram

\section{Gambar 3:}

Kegiatan ke 2 Diskusi pemetaan persoalan pembelajaran dan instrumen PTK melalui metode cermah diskusi, tanya jawab serta praktik bersama nara sumber Lalu Sucipto salah satu dosen FTK UIN Mataram 

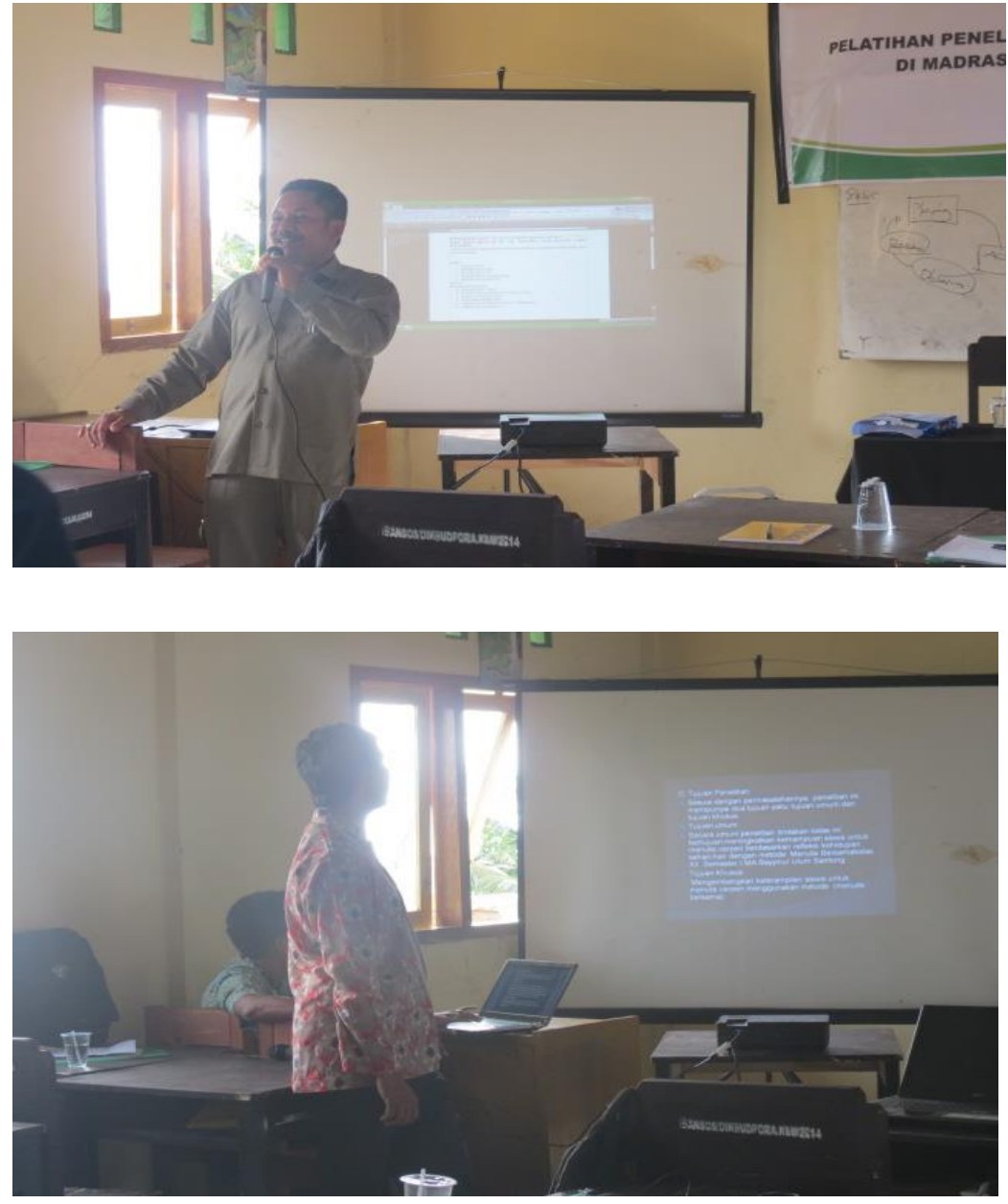

\section{Gambar 4:}

Diskusi proposal dan hasil PTK oleh salah satu guru sebagai peserta sedang presentasi hasil penyusunan proposal PTK dan bediskusi dengan nara sumber

\section{Gambar 5:}

Peyampaian hasil praktik PTK melalui metode ceramah diskusi, tanya jawab serta praktik. Salah satu guru sebagai peserta sedang presentasi hasil penyusunan proposal PTK dan bediskusi dengan nara sumber

Dalam pelaksanaan kegiatan workshop PTK ini dilakukan dengan metode ceramah, Tanya jawab, diskusi grup, demonstrasi dan presentasi dari peserta dengan bantuan bantuan media. Metode ceramah dan Tanya jawab dilakukan untuk menyampaikan berbagai informasi umum mengenai konsep/teori PTK yang prosentasinya 30\% dan sisanya 70\% untuk kegiatan praktik. Konsep/teori hanya difokuskan untuk mereview pengetahuan para guru sehingga ditemukan satu pemahaman tentang PTK. Selanjutnya, metode diskusi dan presentasi dilakukan terkait dengan pemilihan tema-tema yang relevan atau terkait dengan persoalan di kelas yang sifatnya kekinian (khusus persoalan di MAS Bayyinul Ulum) yang dihadapi oleh para guru. Dari sekian tema yang didiganosis maka dipilihlah satu tema yang akan dijadikan sebagai bahan penyusunan proposal PTK.

Proses ini sangat menarik dan menyenangkan. Peserta (para guru) sangatlah antusias dan bisa sharing terkait dengan tema-tema yang muncul dari pada peserta. Selain itu, munculnya tema-tema atau persoalan yang diangkat dari beragam latar dan bidang studi yang diajarkan oleh para guru ada sebagian yang sama tetapi ada juga sebagian yang tidak sama dan sifatnya baru. 
Disinilah urgensinya kegiatan sharing dan duduk bersama untuk berdiskusi sehingga diperoleh satu pengetahuan bahwa satu persoalan pendidikan sangat memungkinkan untuk bisa menggunakan berbagai pendekatan disiplin keilmuan.

Adapun hasil yang diperoleh setelah dilakukan kegiatan workshop/pelatihan

Penelitian Tindakan Kelas (PTK) bagi guru sertifikasi di MAS Bayyinul Ulum antara lain:

\section{1) Para Guru memiliki kemampuan pengetahuan dan praktik tentang PTK.}

Kegiatan workshop atau pelatihan merupakan salah satu cara dalam melaksanakan pembinaan dan pengembangan pengetahuan dan praktik tentang suatu ketrampilan. Begitu juga dengan kegiatan pelatihan PTK di MAS Bayyinul Ulum Santong lokasi yang dijadikan sebagai Madrasah Binaan. Dalam kegiatan itu ditemukan bahwa pada awalnya para guru (peserta) merasa bahwa PTK adalah suatu yang sulit dan asing bagi mereka sehingga ketika meengikuti pelatihan ini dianggap sebagai pengetahuan baru. Bahkan ketika proses workshop berlansung persoalan yang rame ditanyakan adalah apakah PTK sama dengan mengerjakan Skripsi?

Pikiran dan asumsi di atas bisa dimaklumi dan mengingat tugas akhir (skripsi) selalu menjadi momok bagi mahasiswa yang akan menyelesaikan studinya. Sehingga wajar masamasa sulit itu masih dirasakan oleh mereka (para guru-peserta) apalagi bagi sarjana yang alumni PT yang dalam katagori kurang berkualitas. Selain itu, sebagian guru yang sudah memiliki pengetahuan dasar tentang PTK, pelatihan ini dijadikan sebagai review terhadap pengetahuan dan pengalaman tentang PTK sebelumnya. Karenanya, kegiatan workshop pelatihan PTK ini dianggap sangat membantu mereka untuk lebih memahami dan bisa melaksanakan kegiatan PTK di tempat mereka mengajar.

\section{2) Para Guru bisa menganalisis, memetakan dan memilih tema/persoalan PTK.}

Selain materi konsep dan teori tentang PTK, dalam pelatihan ini juga peserta (para guru) diberikan materi bagaimana cara menemukan persoalan yang akan dijadikan tema PTK. Persoalan ini tidak saja dihadapi oleh para guru (peserta), tetapi secara umum para peneliti seringkali mengalami kesulitan dalam menentukan tema atau persoalan penelitian. Kesulitan ini berpengaruh pada ketidakmampuan pada peneliti dalam menentukan judul penelitian yang tepat dan benar.

Pemberian materi di atas dimaksudkan agar para peserta tidak lagi mengalamai kesulitan dalam menetapkan tema/persoalan apa yang dijadikan bahan PTK. Harus diakui bahwa dalam proses pembelajaran, guru dihadapkan pada peserta didik (manusia) yang selalu dinamis dan dipengaruhi oleh lingkungan dan psikologis mereka. Karena itu, secara teori 
psikologis dan social, proses pembelajaran sifatnya kompleks bersamaan dengan munculnya berbagai permasalahan-permasalahan pembelajaran.

\section{3) Para guru memiliki kemampuan dasar dalam menyusun proposal PTK.}

Materi lain yang urgen disampaikan adalah penyusunan proposal PTK. Setelah melalui proses penyampain materi oleh nara sumber, dilanjutkan dengan diskusi dan praktik termbimbing, maka hasil akhir yang teramati adalah peserta telah memiliki kemampuan dalam menyusun proposal PTK.

\section{4) Para guru memiliki kemampuan dalam menyusun instrument PTK.}

Selain materi teori/konsep PTK, peserta juga dibekali dengan cara menyusun intsrumen penelitian tindakan kelas. Instrumen penelitian merupakan bagian penelitian yang harus ada dalam menentukan data lapangan penelitian yang dicari. Dalam proses pelatihan penyusunan materi intsrumen penelitian, semua para peserta sangat antusias dalam setiap menerima materinya. Hal ini disebabkan karena proses pelatihan dilakukan dengan menarik dan partisipatif. Setelah materi disampaikan, kemudian dilanjutkan dengan sesi praktik. Hasil diskusi dengan nara sumber, memang sesi materi ini masih terkendala oleh minimnya pengetahuan peserta tentang instrument penelitian terutama karena keterbatasan referensi yang dimiliki. Selain itu, para peserta tidak pernah melakukan kegiatan ini selama menjadi guru di madrasah binaan.

\section{Kesimpulan}

Dari paparan hasil yang dicapai di atas maka bisa disimpulkan bahwa program Madrasah Binaan di MAS Bayyinul Ulum Santong melalui kegiatan pelatihan PTK dapat dilaksanakan dengan lancar sesuai rncana dan tujuan serta sesuai dengan kebutuhan para guru. Kesadaran akan perlunya melaksanakan kegiatan PTK bagi guru di Madrasah binaan berpotensi bagi terciptanya peningkatan kompetensi professional guru itu sendiri dan juga mutu proses pembelajaran. Kegiatan PTK merupakan suatu keharusan sebagai sebuah solusi dalam menyelesaikan berbagai persoalan pembelajaran. Selain meningkatnya kemampuan para guru tentang PTK secara teoritis, para guru juga memiliki kemampuan dalam menganalisis dan memetakan persoalan yang akan dijadikan bahan PTK, membuat judul PTK dan menyusun proposal PTK serta instrument penelitian.

\section{Ucapan Terima Kasih}

Penulis mengucapkan banyak terima kasih kepada LP2M IAIN Mataram (UIN Mataram) atas kesempatan diberikan kepada penulis dalam melakukan kegiatan Madrasah Binaan. Selain itu juga 
ucapan terima kasih pada tim sejawat Lalu Sucipto dan Sis Putrawangsa atas berkenan membantu kegiatan ini sebagai nara sumber.

\section{Daftar Pustaka}

Nurdin, Muhammmad. 2010. Kiat Menjadi Guru Profesional. Yogyakarta: AR. Ruzz Media Group Ahmadi, Fatah. 2012. Makalah Peran dan Fungsi Guru, (online), (http://edukasi.kompasiana.com/2012/04/27/ diakses 27 April 2012)

Ratnasari, Amelia. 2012. Makalah Guru Profesional, (online), (http://amaliaratnasari.blogspot.com/2012/06/makalah-guru-profesional.html\#ixzz2MsiGLk1L, diakses Juni 2012)

Amat Jaedun. 2008. Prinsip-prinsip Penelitian Tindakan. Makalah Pelatihan PTK Bagi Guru Di Propinsi DIY. Lembaga Penelitian UNY. 2008.

Ani Widayati. 2008. Penelitian Tindakan Kelas. Jurnal Pendidikan Akuntansi Indonesia. Vol. VI. No. 1. Tahun 2008.

Departemen Pendidikan Nasional. 2004. Pedoman Penyusunan Usulan Penelitian Tindakan Kelas Tahun Anggaran 2004.

Departemen Pendidikan Nasional. 2008. Pedoman Block Grant Penelitian Tindakan Kelas Tahun 2008.

Edi Prajitno. 2008. Metode Penelitian Dalam Penelitian Tindakan Kelas. Makalah Pelatihan PTK Bagi Guru Di Propinsi DIY. Lembaga Penelitian UNY. 2008.

Ishariwi. 2008. Identifikasi dan Formulasi masalah Dalam Penelitian Tindakan. Makalah Pelatihan PTK Bagi Guru Di Propinsi DIY. Lembaga Penelitian UNY. 2008.

Jarvis, P. 2001. Learning in Later Life: An Introduction for Educators and Careers. London:

Kogan Page Sukanti. 2008. Meningkatkan Kompetensi Guru Melalui Pelaksanaan Penelitian Tindakan Kelas. Jurnal Pendidikan Akuntansi Indonesia. Vol. VI. No. 1. Tahun 2008.

Kember, David. 2000. Action Learning and Action Research. London: Kogan Page.

Kemmis, Stephen and McTaggart, Robin (1988) The Action Research Planner, 3rd Edition, Deakin University, Geelong.

Lewin, Kurt. 1958. Action Research and Minority Problems, Journal of Social Issues

Pantiwati,Y. 2001. Upaya peningkatan profesionalisme Guru Melalui Program sertifikasi Guru Bidang Studi (untuk guru MI dan MTs). Makalah dipresentasikan, Malang, PSSJ PPs Universitas Malang.

Rustiyah NK. 1986. Masalah-masalah Ilmu Keguruan. Jakarta. Bina Aksara.

Semiawan,C.R. 1999. Mencari Strategi Pengembangan Pendidikan Nasional Menjelang Abad XXI. Jakarta. Grasindo.

UU RI No.20 Tahun 2003 tentang Sistem Pendidikan Nasional. 